\title{
EIF3E wt Allele
}

National Cancer Institute

\section{Source}

National Cancer Institute. EIF3E wt Allele. NCI Thesaurus. Code C53141.

Human EIF3E wild-type allele is located within 8q22-q23 and is approximately $47 \mathrm{~kb}$ in length. This allele, which encodes eukaryotic translation initiation factor 3 subunit $\mathrm{E}$ protein, plays a role in the regulation of the interaction of messenger and transfer RNA with ribosomes. The gene may be involved in tumorigenesis. 